\title{
PENGEMBANGAN BUKU AJAR KEARIFAN LOKAL MALANG RAYA PADA PEMBELAJARAN TEMATIK SISWA KELAS IV SD
}

\author{
Havindah Salsabila ${ }^{1}$, Arina Restian ${ }^{2}$, Ima Wahyu Putri Utami ${ }^{3}$ \\ Pendidikan Guru Sekolah Dasar, Fakultas Keguruan dan Ilmu Pendidikan, \\ Universitas Muhammadiyah Malang ${ }^{1,2,3}$ \\ Email: salsabila20hs@gmail.com
}

\begin{abstract}
Abstrak
Berdasarkan hasil observasi dan wawancara bersama wali kelas IV di SDN 1 Sidorahayu Wagir yang telah dilakukan pada 18 Januari 2021, terdapat permasalahan pada proses pembelajaran yaitu masih banyaknya siswa yang kurang semangat dalam belajar terutama membaca. Hal tersebut dapat mempengaruhi hasil belajar siswa sehingga kurang maksimal dan masih banyak siswa yang kurang mengenal kearifan lokal yang ada di Malang. Melihat permasalahan tersebut dapat diatasi dengan mengembangkan suatu buku ajar yang dapat menarik perhatian siswa. Tujuan dari pengembangan buku ajar kearifan lokal ini untuk menumbuhkan minat belajar siswa melalui pengenalan kearifan lokal sehingga dapat meningkatkan semangat belajar dan dapat menjaga serta melestarikan kearifan lokal di daerah tempat tinggalnya. Penelitian ini menggunakan metode Research and Development (R\&D) dengan model pengembangan ADDIE dengan 5 tahapan, antara lain Analysis, Design, Development, Implementation, dan Evaluation. Hasil penelitian menunjukkan bahwa penggunaan buku ajar kearifan lokal Malang pada pembelajaran tematik kelas IV di SDN 1 Sidorahayu Wagir dapat memotivasi siswa dalam hal membaca.
\end{abstract}

Kata Kunci : Pengembangan Buku Ajar, Kearifan Lokal Malang, Pembelajaran Tematik

\begin{abstract}
Based on the results of observations and interviews with $4^{\text {th's }}$ grade teacher at SDN 1 Sidorahayu Wagir that had been conducted on January 18, 2021, there was problem in the learning process, namely the number of students who were less enthusiastic in reading. This affected student's learning outcomes so that the learning outcomes were less than optimal and there were many students who were not familiar with local wisdom in Malang. To see these problems can be overcome by developing a textbook to attract student's interest in learning through the introduction of local wisdom. So it can increase the spirit of learning as well as maintain and preserve local wisdom in their area where they live. This research uses Research and Development $(R \& D)$ with ADDIE method, including Analyze, Design, Development, Implementation and Evaluation. The result showed that the use Local Wisdom of Malang textbooks in $4^{\text {th }}$ grade of thematic learning at SDN 1 Sidorahayu Wagir could motivate students to learn, especially reading.
\end{abstract}

Key Words : Textbook development, Local wisdom of Malang, Thematic Learning

\section{PENDAHULUAN}

Pembelajaran di sekolah dasar saat ini menggunakan pembelajaran tematik. Menurut Undang-undang No 20 Tahun 2003 Tentang Sisdiknas Pasal 1 Ayat 20, pembelajaran merupakan sebuah proses interaksi antara guru dan siswa yang menggunakan sumber belajar pada suatu lingkungan belajar [1].

Pembelajaran tematik merupakan penggabungan materi dari beberapa mata pelajaran menjadi satu tema. Pembelajaran tematik ialah suatu pembelajaran yang mengaitkan materi dari beberapa mata pelajaran sehingga dapat memberikan pengalaman langsung kepada siswa [2]. Pengalaman tersebut didapatkan secara langsung saat berinteraksi dengan obyek maupun pengalaman di lingkungannya.

Pembelajaran tematik menggunakan prinsip bermain sambil belajar sehingga pembelajaran menyenangkan, dalam pembelajaran ini guru dapat mengaitkan kehidupan sehari-hari siswa secara 
langsung. Pada pelaksanaannya, terdapat komponen penting yang harus diperhatikan seperti perancangan RPP. RPP merupakan rencana pelaksanaan pembelajaran yang akan dilaksanakan pada proses pembelajaran dan pengorganisasian siswa untuk mencapai kompetensi dasar yang akan dilakukan oleh guru dalam satu atau lebih pertemuan [3].

Bahan ajar adalah suatu bahan yang digunakan dalam proses pembelajaran. Salah satu bentuk bahan ajar yang dapat digunakan adalah bahan ajar berbentuk cetak, seperti buku ajar. Buku ajar merupakan alat yang digunakan pendidik untuk membantu siswa mempelajari suatu kompetensi dasar, sehingga mampu menyeluruh. Buku ajar tersebut memudahkan guru untuk mencapai tujuan pembelajaran yang ingin dicapai [4] . Buku ajar memiliki fungsi untuk memudahkan guru dalam memberikan pengetahuan dan memudahkan siswa dalam menerima pengetahuan yang disampaikan. Fungsi dari buku ajar antara lain sebagai pedoman guru dalam proses pembelajaran, sebagai pedoman siswa dalam belajar, sebagai alat evaluasi ketercapaian hasil belajar siswa [5].

Berdasarkan analisis kebutuhan yang telah dilakukan pada tanggal 18 Januari 2021, siswa di SDN 1 Sidorahayu, Wagir, Kabupaten Malang masih banyak yang kurang semangat dalam belajar. Kurangnya semangat dalam membaca dapat membuat siswa mengalami keterlambatan dalam menerima pembelajaran yang diberikan.

Hal tersebut sangat tidak baik dalam perkembangan kognitif siswa. Kearifan lokal di lingkungan tempat tinggal siswa sangat penting untuk dikenalkan agar siswa mengetahui dan memahami kekayaan atau keunikan yang dimiliki daerahnya, dengan demikian siswa akan belajar menjaga melestarikan kearifan lokal di daerahnya.
Pada praktiknya, buku ajar digunakan untuk menjelaskan dan memberikan informasi terkait pengetahuan kepada siswa. Adanya bahan ajar siswa akan lebih mengetahui setiap kompetensi yang harus dikuasai selama pembelajaran berlangsung [6]. Permasalahan yang terjadi saat ini adalah siswa kesulitan dalam menerima materi yang diajarkan sehingga menimbulkan rasa malas dalam diri siswa untuk menerima ilmu yang disampaikan.

Melihat pemasalahan tersebut, maka dikembangkanlah buku ajar kearifan lokal Malang. Buku ajar kearifan lokal Malang ini sesuai dengan kompetensi dasar (KD), indikator dan tujuan pembelajaran yang telah dirancang sebelumnya. Pendidikan berbasis kearifan lokal dapat mengajarkan siswa agar selalu dekat dengan lingkungan sehari-hari. Pendidikan berbasis kearifan lokal mampu mengembangkan kecakapan dan kemampuan siswa terutama dalam melestarikan potensi masing-masing daerah [7].

Tujuan dari pengembangan buku ajar kearifan lokal ini untuk menumbuhkan minat belajar siswa dengan cara mengenalkan kearifan lokal, sehingga semangat dalam belajar dapat meningkat. Kearifan lokal merupakan suatu kebiasaan yang digunakan masyarakat untuk menuntun ke dalam kehidupan yang telah diwariskan secara turun temurun. Kearifan lokal yaitu kearifan (wisdom) memiliki arti kebijaksaan sedangkan lokal (local) memiliki arti setempat [8].

Jadi dapat disimpulkan bahwa local wisdom atau kearifan lokal merupakan gagasan, nilai pandangan masyarakat setempat yang memiliki sifat kebijaksanaan, penuh kearifan sehingga membentuk nilai yang baik dan tertanam serta diikuti oleh masyarakat setempat. 
Kearifan lokal dapat digunakan sebagai cara dalam menjaga kekayaan yang dimiliki oleh suatu daerah dan suatu cara untuk menanamkan nilai positif pada masyarakat khususnya kepada siswa agar tidak terpengaruh budaya negatif dari luar. Peran dari kearifan lokal adalah untuk mengurangi dampak globalisasi dengan cara menanamkan nilai-nilai positif kepada masyarakat. Penanaman tersebut berdasarkan pada nilai, norma serta adat istiadat pada setiap daerah [9]. Nilai tersebut dimiliki oleh setiap daerah salah satunya di Malang.

\section{METODE}

Penelitian ini menggunakan metode Research \& Development (R\&D). Penelitian ini bertujuan mengembangkan buku ajar untuk meningkatkan pemahaman siswa dalam proses pembelajaran serta mengenalkan kearifan lokal di Malang. Pengembangan buku ajar kearifan lokal Malang ini menggunakan model ADDIE.

Model ADDIE memiliki 5 tahapan antara lain analysis, design, development, implementation, and evaluation [10]. Model ADDIE cocok digunakan untuk produk pengembangan seperti buku ajar.

Teknik pengumpulan data dalam penelitian ini dilakukan dengan cara observasi, wawancara yang dilakukan dengan wali kelas kelas IV di SDN 1 Sidorahayu, dokumentasi berupa foto, video, dan dokumen penting, angket atau yang digunakan untuk mengumpulkan data validasi dari para ahli.

Angket validasi ahli materi berupa pertanyaan atau pernyataan yang berhubungan dengan materi dalam bahan ajar. Angket tersebut menggunakan jawaban tertutup. Adapun kisi-kisi angket validasi ahli materi sebagai berikut :
Tabel 1. Kisi-kisi Angket Validasi Materi

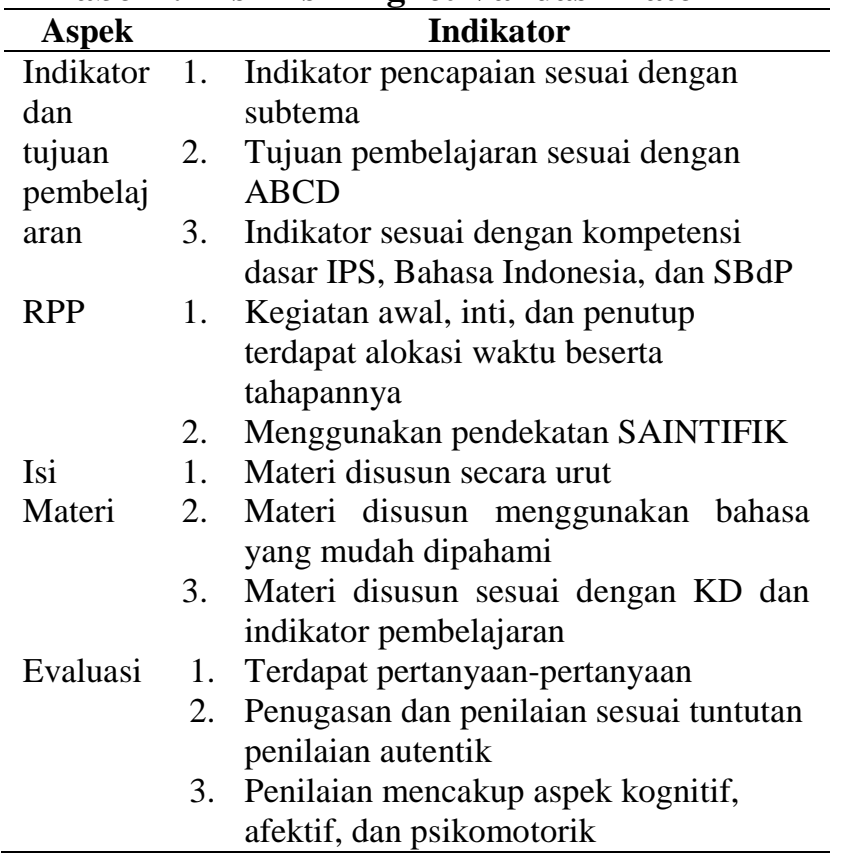

Angket validasi ahli bahan ajar berisi beberapa pertanyaan dengan jawaban tertutup. Pertanyaan tersebut berhubungan dengan bahan ajar. Adapun kisi-kisi angket validasi ahli bahan ajar sebagai berikut :

Tabel 2. Kisi-kisi Angket Validasi Bahan Ajar

\begin{tabular}{|c|c|}
\hline Aspek & Indikator \\
\hline $\begin{array}{l}\text { Tampilan } \\
\text { buku ajar }\end{array}$ & $\begin{array}{l}\text { 1. Tampilan desain cover sesuai } \\
\text { tema } \\
\text { 2. Pemilihan gambar sesuai } \\
\text { kompetensi yang harus dicapai } \\
\text { 3. Ukuran buku A4 } \\
\text { 4. Ketepatan warna huruf dan } \\
\text { angka } \\
\text { 5. Ketepatan ukuran font } \\
\text { 6. Sistematika penulisan isi buku } \\
\text { sesuai EYD }\end{array}$ \\
\hline $\begin{array}{l}\text { Penggunaan } \\
\text { Bahasa }\end{array}$ & $\begin{array}{l}\text { 1. Pemilihan teks sesuai dengan } \\
\text { kompetensi yang harus dicapai } \\
\text { 2. Bahasa yang digunakan efektif }\end{array}$ \\
\hline
\end{tabular}

Angket validasi ahli pembelajaran diberikan kepada guru atau wali kelas IV di SDN 1 Sidorahayu Wagir. Angket tersebut berisi beberapa pertanyaan atau pernyataan yang berhubungan dengan proses pembelajaran. Adapun kisi-kisi angket validasi ahli materi sebagai berikut: 
Tabel 3. Kisi-kisi Angket Validasi Ahli Pembelajaran

\begin{tabular}{|c|c|}
\hline Aspek & Indikator \\
\hline $\begin{array}{l}\text { Pengkondisian } \\
\text { kelas }\end{array}$ & $\begin{array}{l}\text { 1. Bahan ajar mudah diterapkan } \\
\text { dalam pembelajaran } \\
\text { 2. Bahan ajar memudahkan } \\
\text { siswa bekerja sama } \\
\text { 3. Bahan ajar menciptakan } \\
\text { pembelajaran yang } \\
\text { menyenangkan }\end{array}$ \\
\hline $\begin{array}{l}\text { Keterlibatan } \\
\text { siswa }\end{array}$ & $\begin{array}{l}\text { 1. Bahan ajar meningkatkan } \\
\text { keaktifan siswa dalam } \\
\text { pembelajaran } \\
\text { 2. Bahan ajar meningkatkan } \\
\text { partisipasi siswa dalam } \\
\text { pembelajaran }\end{array}$ \\
\hline
\end{tabular}

Setelah pengumpulan data, maka data perlu diolah atau dianalisis. Teknik analisis data dalam penelitian ini yaitu menggunakan teknik analisis data kualitatif dan kuantitatif. Teknik analisis data kualitatif digunakan untuk menggambarkan suatu permasalahan kemudian menjelaskannya secara sistematis. Penelitian ini menggunakan sumber data primer yang diperoleh dari narasumber secara langsung dan data sekunder yang diperoleh melalui data pendukung seperti buku, jurnal, artikel dan penelitian terdahulu. Teknik analisis data kuantitatif digunakan untuk mengetahui kelayakan buku ajar kearifan lokal Malang. Teknik analisis data kuantitatif pada penelitian ini menggunakan skala yaitu skala Likert. Skala Likert ialah skala yang digunakan untuk mengukur persepsi, sikap atau pendapat [11]. Skala Likert digunakan untuk mengukur variabelvariabel yang terkait dengan peneliti . Skala Likert ini digunakan untuk menganalisis data angket validasi para ahli dan respon siswa dengan pernyataan tertutup. Adapun rentang skala penilaian sebagai berikut:

Tabel 4. Skala Likert

\begin{tabular}{ccc}
\hline No & Skor & Keterangan \\
\hline 1 & Skor 4 & Sangat baik \\
2 & Skor 3 & Baik \\
3 & Skor 2 & Kurang \\
4 & Skor 1 & Sangat kurang \\
\hline
\end{tabular}

Presentase yang diperoleh dari beberapa ahli validasi dapat diperoleh dari rumusan sebagai berikut :

Keterangan :

$$
f=\frac{\Sigma \mathrm{R}}{N} \times 100 \%
$$

$\mathrm{f}=$ Presentase

$\Sigma R=$ Skor yang diperoleh

$\mathrm{N}=$ Skor maksimal

Data yang telah dihitung presentasenya, disesuaikan dengan kriteria keefektifan yang sudah dirancang menggunakan instrumen penelitian. Kriteria keefektifan buku ajar kearifan lokal Malang adalah sebagai berikut :

Tabel 5. Keefektifan Kelayakan

\begin{tabular}{ccc}
\hline No & $\begin{array}{c}\text { Tingkat } \\
\text { pencapaian }\end{array}$ & Keterangan \\
\hline 1 & $85,1 \%-100 \%$ & Sangat valid, tanpa revisi \\
2 & $70,1 \%-85 \%$ & Valid, sedikit revisi \\
3 & $50,1 \%-70 \%$ & Kurang valid, banyak revisi \\
4 & $0 \%-50 \%$ & Tidak valid, tidak layak \\
\hline
\end{tabular}

\section{HASIL DAN PEMBAHASAN}

Pengembangan dan penelitian ini dilakukan pada kelas IV semester genap di SDN 1 Sidorahayu Wagir. Penelitian ini menghasilkan bahan ajar berupa buku ajar kearifan lokal Malang berbasis tematik.

Buku ajar kearifan lokal ini digunakan untuk menumbuhkan semangat belajar siswa, dilihat dari proses penerapan buku ajar serta mengenalkan kepada siswa tentang kebudayaan yang ada di lingkungan tempat tinggalnya.

Pengembangan buku ajar kearifan lokal berbasis tematik menggunakan model ADDIE, adapun tahap-tahap yang sudah dilakukan sebagai berikut :

\section{a. Analysis}

Analysis berupa analisis masalah yang terdapat di SDN 1 Sidorahayu Wagir. Pengumpulan informasi dilakukan melalui wawancara bersama wali kelas IV SD pada 18 Januari 2021. 
Hasil analisis menunjukkan bahwa masih banyak siswa yang kurang semangat dalam membaca sehingga siswa mengalami keterlambatan dalam menerima pengetahuan. Selain itu, kurangnya penyampaian materi kearifan lokal di lingkungan tempat tinggal siswa sehingga masih banyak siswa yang kurang mengenal budaya di lingkungannya, dan hanya menggunakan buku tematik yang membahas kebudayaan Indonesia secara umum serta kurangnya pemberian variasi sehingga siswa mudah merasa bosan dalam belajar.

Melihat hal tersebut, maka dilakukan pengembangan buku ajar kearifan lokal Malang sebagai bahan ajar yang dapat digunakan oleh guru dan siswa kelas IV pada pembelajaran tematik di SDN 1 Sidorahayu Wagir.

\section{b. Design}

Pada ada tahap ini produk yang akan dirancang berupa buku ajar harus sesuai dengan RPP yang telah dibuat sebelumnya. RPP tersebut memuat KD, indikator, tujuan pembelajaran dengan menggunakan ABCD (Audience, Behavior, Condition, Degree), kegiatan awal hingga penutup, uraian materi, LKPD, lembar evaluasi beserta rubrik penilaian.

Buku ajar kearifan lokal ini mengacu pada tema 7 "Indahnya Keragaman di Negeriku", subtema 2 "Indahnya Keragaman Budaya Negeriku", dengan mentematikkan mata pelajaran IPS, Bahasa Indonesia, dan SBdP. Pada tahap ini juga dilakukan pengumpulan objek rancangan dan penyusunan instrument untuk menguji kelayakan buku ajar dalam pembelajaran.

\section{c. Development}

Pembuatan buku ajar kearifan lokal Malang memiliki dua tahapan, antara lain desain buku ajar, dan hasil validasi buku ajar.

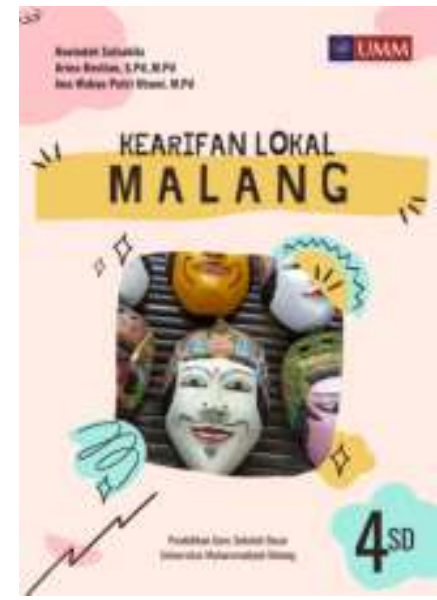

\section{Gambar 1. Cover Depan Buku Ajar}

Pada gambar 1 terdapat cover depan buku ajar berjudul Kearifan Lokal Malang. Pada cover depan terdapat identitas penulis, judul, logo Universitas Muhammadiyah Malang (UMM), gambar cover, dan kelas yang dapat menggunakan buku tersebut yaitu kelas IV SD.

Pada buku ajar juga terdapat kompetensi dasar, indikator dan tujuan pembelajaran yang sesuai dengan ABCD.

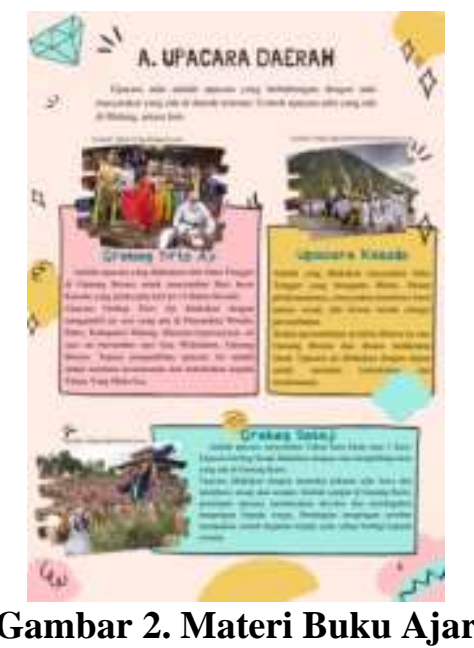

Materi kearifan lokal Malang, antara lain upacara, tarian, kesenian, warisan budaya Malang, dan lagu "Malang Pancen Rame". Pada materi tidak hanya terdapat tulisan tetapi juga terdapat gambar menarik. 
Pada Buku ajar kearifan lokal Malang terdapat LKPD 1, LKPD 2 dan LKPD 3, serta terdapat lembar evaluasi yang digunakan untuk mengukur hasil belajar siswa setelah mempelajari buku kearifan lokal Malang.

Buku ajar kearifan lokal Malang juga dilengkapi dengan rubrik penilaian yang mencakup mata pelajaran IPS, Bahasa Indonesia, dan SBdP dan sudah sesuai dengan ketiga aspek yang ingin dicapai yaitu aspek kognitif, afektif, dan psikomotorik.

Selanjutnya buku ajar kearifan lokal Malang tersebut diuji kelayakannya oleh validasi ahli materi dan ahli bahan ajar. Hasil validasi ahli materi digunakan untuk mengetahui kelayakan isi pada buku ajar. Adapun hasil penilaian yang didapatkan yaitu 48. Sedangkan skor yang diharapkan adalah 68, maka perhitungan presentase dengan rumus sebagai berikut :

$$
\begin{aligned}
& \text { Presentase kelayakan }= \\
& \quad \begin{array}{c}
\text { jumlah skor didapat } \\
\text { jumlah skor harapan }
\end{array} \times 100 \%= \\
& \frac{46}{52} \times 100 \%=88 \%
\end{aligned}
$$

Jadi, hasil kelayakan materi pada buku ajar kearifan lokal Malang sebesar $88 \%$ yang dinyatakan valid untuk diujicobakan pada siswa kelas IV SD. Dilanjutkan dengan validasi ahli bahan ajar dengan hasil skor yang didapatkan adalah 38 sedangkan skor yang diharapkan adalah 40, maka perhitungan presentase sebagai berikut :

$$
\begin{aligned}
& \text { Presentase kelayakan }= \\
& \qquad \begin{array}{c}
\text { jumlah skor didapat } \\
\text { jumlah skor harapan }
\end{array} \text { 100\% }= \\
& \frac{38}{40} \times 100 \%=95 \%
\end{aligned}
$$

Jadi, hasil kelayakan bahan ajar berupa buku kearifan lokal Malang sebesar 95\% yang sangat layak dan valid untuk diujicobakan kepada siswa kelas IV SD.
Hasil validasi berupa saran akan diperbaiki oleh peneliti sesuai dengan saran para ahli sebelum diimplementasikan.

\section{d. Implementation}

Buku ajar kearifan lokal Malang telah selesai dikembangkan dan diterapkan pada siswa kelas IV di SDN 1 Sidorahayu Wagir pada 28 Mei dan 31 Mei 2021.

Pada implementasinya, peneliti mengambil sampel 8 siswa karena masih berada dalam masa pandemi sehingga masih belum diperbolehkan pembelajaran tatap muka dengan banyak siswa dan terdapat pembatasan waktu yaitu maksimal dua jam. Pelaksanaan pembelajaran dilakukan dengan mematuhi protokol kesehatan. Hal tersebut dilakukan untuk menjaga kesehatan di masa pandemi COVID-19.

Siswa diminta berpasangan dan peneliti membagikan buku ajar kearifan lokal Malang yang didalamnya memuat materi upacara adat, tarian daerah, kesenian daerah.

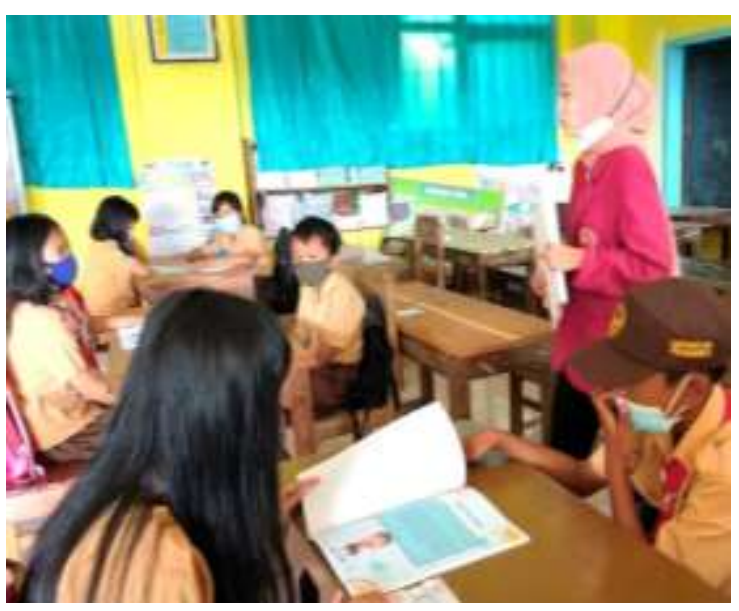

Gambar 3. Implementasi Buku Ajar

Siswa diminta untuk membaca bersamasama buku ajar tersebut. Dilanjutkan dengan mengerjakan LKPD yang telah dikembangkan. kegiatan terakhir yaitu siswa diminta untuk mengerjakan lembar 
evaluasi. Adapun hasil nilai kognitif siswa sebagai berikut :

Tabel 6. Nilai Kognitif Siswa

\begin{tabular}{ccc}
\hline No & Nama siswa & Nilai kognitif \\
\hline 1 & A & 100 \\
2 & AA & 100 \\
3 & AC & 80 \\
4 & AI & 20 \\
5 & B & 80 \\
6 & DA & 96 \\
7 & FI & 68 \\
8 & H & 98 \\
Nilai rata-rata kelas & $\mathbf{8 0 , 2 5}$ \\
\hline
\end{tabular}

Berdasarkan hasil evaluasi siswa menunjukkan bahwa buku ajar kearifan lokal Malang yang telah dikembangkan mendapat hasil yang efektif. Hal tesebut ditunjukkan dengan hasil nilai rata-rata kelas diatas mendapatkan nilai sebesar 80,25 .

\section{e. Evaluation}

Evaluasi tersebut dibagi menjadi dua macam yaitu evaluasi formatif diperoleh dari hasil validasi ahli materi, bahan ajar, dan pembelajaran, serta analisis data dari siswa kelas IV SD melalui angket. Hasil penilaian siswa adalah sebesar 91\% termasuk pada kategori sangat layak digunakan pada proses pembelajaran.

Evaluasi sumatif dilakukan dengan melihat nilai rata-rata kelas yaitu 80,25. Hasil tersebut sudah melebihi nilai ketuntasan minimal yang telah ditetapkan yaitu 75 . Buku ajar kearifan lokal digunakan sebagai bahan ajar dalam pembelajaran yang menjadikan aktivitas pembelajaran lebih efektif dan interaktif serta membantu siswa untuk belajar mandiri [12].

Salah satu contoh nilai positif yang ada pada buku ajar Kearifan Lokal Malang adalah saling berbagi. Nilai tersebut terdapat pada salah satu upacara adat di Malang yaitu Grebeg Sesaji yang disimbolkan dengan pembagian tumpeng. Buku ajar kearifan lokal Malang merupakan buku ajar pembelajaran tematik karena mengaitkan beberapa mata pelajaran yang memiliki kesamaan tema menjadi satu tema [13].

Pada penelitian dan pengembangannya, buku ajar kearifan lokal terdapat beberapa saran dari validator yang harus dipenuhi untuk menjadikan buku ajar semakin baik sebagai bahan ajar dalam pembelajaran. Adapun hasil validasi dari para ahli yang digunakan untuk menilai kelayakan buku ajar ini sebagai berikut: hasil validasi ahli materi sebesar $88 \%$, hasil validasi ahli bahan ajar sebesar $95 \%$, dan validasi ahli pembelajaran sebesar 98\%. Setelah divalidasi, dilanjutkan dengan melakukan implementasi dan mendapatkan hasil ratarata angket siswa sebesar $91 \%$.

\section{SIMPULAN}

Pengembangan buku ajar kearifan lokal Malang menggunakan metode R\&D dan model ADDIE. Buku ajar kearifan lokal ini digunakan untuk siswa kelas IV SD yang telah dikembangkan sesuai dengan Tema7 "Indahnya Keragaman di Negeriku" subtema2.

Buku ajar kearifan lokal Malang ini merupakan buku ajar berbasis tematik yang telah dinyatakan valid, karena telah divalidasi oleh para ahli dan teruji kelayakannya. Adapun hasil presentase yang telah diperoleh dari validasi ahli materi adalah $88 \%$, validasi ahli bahan ajar adalah $95 \%$, dan validasi ahli pembelajaran sebanyak 98\%. Sedangkan hasil respon siswa sebanyak 91\%, sehingga dapat disimpulkan bahwa buku ajar kearifan lokal Malang yang telah dikembangkan dapat digunakan sebagai bahan ajar dalam proses pembelajaran tematik di kelas IV SDN 1 Sidorahayu Wagir.

\section{DAFTAR PUSTAKA}

[1] "UU No 22 Tahun 2003 Tentang Sistem Pendidikan Nasional.” 2003. 
https://peraturan.bpk.go.id/Home/Det ails/43920/uu-no-20-tahun-2003

(diakses Sep 21, 2021)

[2] N. Sudjana, Model Pembelajaran Tematik Kelas Awal Sekolah Dasar. Bandung: Remaja Rosdakarya, 2006.

[3] Gunawan dan A. Asrifan, "Penerapan Kerja Kelompok Kegiatan MGMP Guru Ekonomi dalam Menyusun RPP untuk Meningkatkan Kompetensi Pedagogik," vol. 02, Celebes Education Review, Apr 2020. http://journal.1ldikti9.id/CER/index

[4] N. Sudjana, Penilaian Hasil Proses Belajar Mengajar. Bandung: PT Remaja Rosdakarya, 2009.

[5] Depdiknas, "Standar Isi Untuk Satuan Pendidikan Dasar dan Menengah." Dirjen Dikti Depdiknas, 2007.

[6] I. Magdalena, T. Sundari, S. Nurkamilah, Nasrullah, dan D. A. Amalia, "Analisis Bahan Ajar," vol. 2, no. Nusantara: Jurnal Pendidikan dan Ilmu Sosial, 2020.

https://ejournal.stitpn.ac.id/index.php /nusantara

[7] Nadlir, "Urgensi Pembelajaran Berbasis Kearifan Lokal," vol. 02, no. Jurnal Pendidikan Agama Islam, Nov 2014.

http://repository.uinsby.ac.id/id/eprin t/806/

[8] KBBI, "Kamus Besar Bahasa Indonesia."

[9] M. R. Al Musafiri, "Peran Kearifan Lokal Bagi Pengembangan Pendidikan Karakter Pada Sekolah Menengah Atas," vol. 8. Jurnal Darussalam: Jurnal Pendidikan, Komunikasi dan Pemikiran Hukum Islam, hlm. 1-9, 2017.

[10] T. I. Made dan N. Jampel, Model Penelitian dan Pengembangan. Yogyakarta: Graha Ilmu, 2014.

[11] V. H. Pranatawijaya, Widiatry, P. Ressa, dan P. B. A. Putra,
"Pengembangan Aplikasi Kuisioner Survey Berbasis Web Menggunakan Skala Likert dan Guttman," vol. 5, 2019.

[12] F. Zaenol, "Bahan Ajar Tematik dalam Pelaksanaan Kurikulum 2013," vol. 05, no. Jurnal Pedagogik, 2018.

https://ejournal.unuja.ac.id/index.php /pedgogik

[13] N. Hidayah, "Pembelajaran Tematik Integratif di Sekolah Dasar," vol. 2, no. Jurnal Terampil Pendidikan dan Pembelajaran Dasar, 2015. 